\title{
Sheepskin Effect in Guatemala. Years 2002 and 2018.
}

\author{
Guillermo Díaz* \\ Rafael Landivar University Guatemala
}

*Corresponding Author: Guillermo Díaz, Rafael Landívar University Guatemala

\begin{abstract}
This research provides empirical evidence on the existence of the sheepskin effect in Guatemala. For this purpose, based on data from Income Employment Surveys for the years 2002 and 2018, an estimate of the Mincer model was made according to complete and incomplete educational level. The estimation was made by ordinary least squares and Heckman two-stage methods to control for selection bias. The results confirm the existence of the sheepskin effect in the three educational levels investigated. They also provide evidence of a devaluation of academic degrees in 2018 compared to 2002.
\end{abstract}

\section{INTRODUCTION}

The returns to education show a downward trend worldwide, according to a study by the World Bank (2014). The situation in some Latin American countries is such that, in Peru, Yamada (2007) published a study that includes in the title the question Is it worth the effort? To refer to the cost, both in time and opportunity, which it involves studying for a degree. Villaroel and Hernani (2011), in Bolivia, were more forceful in this regard, when asking, Does education still pay? Added to the above is the decision of global companies, such as Apple, Google, Netflix or Siemens, not to require a university degree as a requirement to hire (Forbes, 2019).

In Guatemala, a survey of 209 companies, the majority (86\%) of medium and large size, revealed that slightly less than $20 \%$ of hired workers have university studies. The majority, almost $50 \%$, have studies at the secondary level. The survey also revealed that companies hire workers with certifications (Fundesa, 2020).

Given the trends described, questions arise such as: Is the phenomenon of reduction in returns to education and degrees (sheepskin effect or diploma) observable in Guatemala? Is the phenomenon also observed in pre-university studies? How much premium does the Guatemalan labor market pay because the worker has a university degree?

The interest in researching the diploma effect arises from the motivation to know the effect of the massification of graduates at the secondary and university level, which occurred during the first two decades of the 21 st century in Guatemala, on the returns of academic diplomas. In the first case, the annual number of graduates went from 84,111 in 2006 to 158,161 in 2018 (Ministry of Education, 2019). The number of people who in the 2018 population census reported having obtained a high school diploma was almost 1.8 million (National Institute of Statistics, 2018). For its part, the annual number of university graduates increased from 9,584 in 2007 to 32,075 in 2017. In the 2018 census, the number of people who reported having a university degree was around 619,000 (National Institute of Statistics, 2019). In this sense, a first approximation to statistical data available from 2010 to 2015 reveals a devaluation of university degrees, as illustrated in the following table 1 . In this table it can be observed that as the annual number of university graduates increased, the average monthly salary decreased.

Table1. Guatemala: Average monthly salary and number of university graduates

\begin{tabular}{|l|c|c|}
\hline Year & Average monthly salary & Number of university graduates \\
\hline 2010 & 6,485 & 14,450 \\
\hline 2011 & 6,016 & 19,990 \\
\hline 2012 & 7,551 & 20,831 \\
\hline 2013 & 6,342 & 24,442 \\
\hline 2014 & 5,891 & 26,899 \\
\hline 2015 & 5,750 & 33,680 \\
\hline
\end{tabular}


Source: DIGI, 2014 e NSI, 2017.

In Guatemala, there are few studies on returns to education that can be consulted. Among the few that could be accessed are those of Pérez (2003), Saidón (2004), Alejos (2006), World Bank (2011), and Díaz (2019). The first three studies refer to the year 2000 and the World Bank to the years 2000 and 2006. The last is an analysis of comparative statics between the years 2002 and 2006. In the literature review on the subject, no one could be found. Research on the sheepskin effect in Guatemala. The research presented here contributes to estimating the sheepskin effect in Guatemala for the years 2002 and 2018.

The research question is, What was the value of the sheepskin effect in Guatemala in the years 2002 and 2018? The same question is also asked based on the sex of the people. The research is carried out for those years based on being the first and most recent in the publication of the National Survey of Employment and Income, whose data were used to estimate the sheepskin effect.

\section{LITERATURE REVIEW.}

Capital theory is useful for understanding the relationship between income and education. This theory postulates that people can improve their skills through education or training on the job. Investment in education or training is considered an investment in human capital in the sense that it improves people's physical and mental abilities and, consequently, increases their future income (Becker, 1962). In the economic literature, there are various approaches to estimate the relationship between income and education.

The most widely used is the Mincer (1974) model, which quantifies the increase in income per year of studies. From this model, others are derived that calculates income according to the educational level completed, through the Spline technique, or completed or unfinished educational level. The latter is known in the economic literature as the sheepskin effect and comprises increases in income from obtaining a sheepskin or completing an academic degree (Harmon, Oosterbeek\&Wlaker, 2003). Mincer's model has theoretical questions, such as the measurement of income that comes from people's innate abilities. This problem is corrected, to some extent, when estimating the returns to education according to the sheepskin effect model, since, according to the signaling theory, the more educated obtain higher returns for their innate abilities. It also postulates that such income is obtained as long as the years of education are certified and marked as degrees in the labor market (Spence, 2002). The employer uses the credentials or academic titles as a signal of the worker's productivity and he as a signal to be selected (Stiglitz, 2002).

One of the first studies to verify the signaling theory was elaborated by Layard and Psacharopoulos (1974), who concluded that the sheepskin effect did not exist, by not finding differences in returns between people with completed and not completed degrees. The first study that empirically verified the sheepskin effect was carried out by Hungerford and Solon (1987), who found income differences between people with a complete and incomplete university education, with returns of $13 \%$ versus $4 \%$, respectively. Since then, numerous studies have been carried out on the sheepskin or sheepskin effect, although not as much as on the returns per year of education. A quick Google search in December 2020 returned 360,000 documents for the first topic, against nearly 5,000 for the second. Among the most recent works published and reviewed for this research, we can mention those of Rivera (2015) that addresses the issue in Ecuador, that of Klapp and Candia (2016), that estimated the sheepskin effect for Chile, that of Parodi, Ramírez, and Thomson (2017), prepared for the Dominican Republic and Hernández (2019), focused on Colombia.

\section{Model ANd DATA.}

Mincer (1974) proposed the basic model for estimating returns to education, especially for each year of study, as follows:

$\mathrm{Ln} \mathrm{W} \_\mathrm{j}=$ constant $+\beta \_\mathrm{s} s \_\mathrm{j}+\beta \_$e experience $+\beta \_$el experience 2

The term $\mathrm{j}$ refers to individual $\mathrm{j}$. Following Mincer (1974), the expected values for the parameters $\beta \_0$ and $\beta \_1$ are greater than zero and less than zero for $\beta$ e1, which corresponds to the experience squared. The parameter $\beta \_$s estimates the return on years of education and the parameters $\beta$ e and 
$\beta \_$e1 the return on experience and experience squared. In the first two the returns are increasing and in the third decreasing.

Mincer's basic model is modified using the spline technique, a term that merges the English words "Split" and "line". This means assuming that the relationship between income and years of education is not linear, as Mincer suggested in his model (Rivera, 2015). The modification is made according to the educational levels in force in Guatemala, to estimate sheepskin effect, as follows, taking into consideration only the high school, college and postgraduate levels, considering that in Guatemala they are those that extend degrees that enable for the labor market:

LnW $=\beta \_0+\beta \_1$ high school incomplete $+\beta \_2$ high school complete $+\beta \_3$ college incomplete + $\beta \_4$ college complete $+\beta \_5$ postgraduate incomplete $+\beta \_6$ postcomp $++\beta \_7$ area $+\beta \_8$ sex $+\beta \_9$ experience $+\beta \_10$ experience $2+\varepsilon$

Where:

$\mathrm{LnW}=\mathrm{Ln}$ income, represented by the monthly salary.

$\beta \_1$ high school incomplete $=$ dummy variable with value 0 if it doesn't have it and 1 if it does.

$\beta \_2$ high school complete $=$ dummy variable with value 0 if it doesn't have it and 1 if it does.

$\beta \_3$ college incomplete $=$ dummy variable with value 0 if it does not have and 1 if it does.

$\beta \_4$ college complete $=$ dummy variable with value 0 if it does not have it and 1 if it does.

$\beta$ _ 5 postgraduate incomplete $=$ dummy variable with value 0 if it doesn't have it and 1 if it does.

$\beta \_6$ postgraduate complete $=$ dummy variable with value 0 if it doesn't have it and 1 if it does.

$\beta_{-} 7$ area $=$ geographic area with a value equal to 0 for rural and 1 for urban.

$\beta \_8$ sex $=$ sex, with a value of 0 for women and 1 for men.

$\beta \_9$ experience $=$ age minus 18 years of education.

$\beta \_10$ experience $2=$ age minus age of majority or 18 years of education squared.

Two of the assumptions of the Mincer model are that there is no skill or omitted variable bias and there is no self-selection (Sapelli, 2003). However, a problem in estimating educational returns models, such as the previous one, which calculates the sheepskin effect, is that of self-selection, in the sense of people who decide not to enter the labor market, so that students returns may be underestimated (Ordaz, 2007). To correct for the possible existing self-selection bias, the Heckman (1979) model is used in two stages. The first one estimates the omitted variable, the inverse Mills ratio $(\lambda)$, using a probit model that calculates the probability of people being in the employed population. The second stage includes the inverse Mills ratio as an explanatory variable in Mincer's model. The calculation of the inverse Mills ratio was estimated according to the previous model plus the following variables that explain the choice of joining the labor market or not:

$\mathrm{P}=\lambda$ (constant $+\beta \_\mathrm{ss} \mathrm{j}+\beta \_$e marital status $+\beta \_\mathrm{t}$ household size $+\beta \_\mathrm{i}$ other income)

Where:

$\mathrm{P}=$ Probability of belonging to the employed population.

Marital status $=$ Dichotomous variable with value 0 for single and 1 for non-single

Household size $=$ Number of household members.

Other income $=$ Non-salary income.

The data to estimate the model were obtained from ENEI 2002 and ENEI 2018, both referring to November (NSI, 2003 and 2018). The sample was made up of people aged 18 and over, of both sexes, living in urban and rural areas. In 2002 the sample was 1,477 people and in 2018 3,518. The data to measure the sheepskin effect, that is, who completed an educational level or not, were obtained from 
the variable that indicates the name of the degree obtained. In this sense, those who reported studying at an educational level, but did not report the name of the title, were considered incomplete at that level. The following table summarizes the main descriptive statistics:

Table2. Statistics by according to sex

\begin{tabular}{|l|l|l|l|l|}
\hline & 2002 & & 2018 & \\
\hline Variable & Mens & Women & Mens & Women \\
\hline Years of education & 7 & 6 & 11 & 9 \\
\hline Age & 34 & 32 & 35 & 34 \\
\hline Experience & 17 & 14 & 18 & 17 \\
\hline Monthly salary & 2,784 & 2,490 & 3,102 & 2,990 \\
\hline Source: NSI, 2003 y 2018. & & & \\
\hline
\end{tabular}

Table 2 reveals similarity between the data for 2002 and 2018, in terms of age and years of experience. In years of education and average salary, an increase is observed in 2018 compared to 2002.

\section{Results}

The Mincer (1974) model according to complete and incomplete educational level was estimated with ordinary least squares, using the Gretl software, which allowed to verify that the estimated regressions comply with the assumptions of the model, especially those related to the absence of the typical heteroskedasticity problem. in cross-sectional models.

The estimation of the sheepskin effect for the years 2002 and 2018, calculated based on the ordinary least squares and two-stage methods of Heckman (1979), are presented in table 3. The Heckman model checks the existence of self-selection, given the statistical significance of the variable Lambda at the $1 \%$ level. Consequently, in both years the sample is non-random, so the analysis of the results must be carried out based on the Heckman model. This model shows that for the year 2002 the variables other income and marital status were statistically significant to explain the decision of people not to join the labor market. In 2018 only the household size variable, measured by the number of children, was significant. The Lambda sign for this year indicates that people with higher abilities were excluded from the labor market. In practice, this work is assumed to be a lack of information bias.

Table3. Guatemala: Sheepskin effect.

\begin{tabular}{|c|c|c|c|c|}
\hline Mincer equation & 2002 & & 2018 & \\
\hline according to educational level & $\mathrm{MCO}$ & Heckman & $\mathrm{MCO}$ & Heckman \\
\hline Area & $0.09840 * *$ & $0.188061 *$ & $0.148336^{*}$ & $0.117612 *$ \\
\hline Sex & $0.149700 *$ & $0.303008 *$ & $0.106364 *$ & $0.260400 *$ \\
\hline Experience & $0.023071 *$ & $0.037093 *$ & $0.023204 *$ & $0.023421 *$ \\
\hline Experience squared & $-0.000323 *$ & $-0.000633^{*}$ & $-0.000318^{*}$ & $-0.000167^{*}$ \\
\hline High school incomplete & $0.201871 *$ & $0.226540 *$ & $0.200554 *$ & $0.259009 *$ \\
\hline High school complete & $0.404316^{*}$ & $0.549901 *$ & $0.415127 *$ & $0.378776^{*}$ \\
\hline College incomplete & $0.626869 *$ & $0.720419 *$ & $0.620409 *$ & $0.562271 *$ \\
\hline College complete & $1.13032 *$ & $1.26989 *$ & $0.945375^{*}$ & $0.865067 *$ \\
\hline Postgraduate incomplete & $1.09787 *$ & $1.01864 *$ & $1.183240^{*}$ & $1.059690 .^{*}$ \\
\hline Postgraduate complete & $1.74555 *$ & $1.32828 *$ & $1.307120^{*}$ & $1.186380 *$ \\
\hline Lambda & & $0.60443 *$ & & $-0.617205^{*}$ \\
\hline Constant & $6.82897 *$ & $6.45035 *$ & $7.135650^{*}$ & $7.036210 *$ \\
\hline Selection equation & & & & \\
\hline Other income & & $-3.39232 \mathrm{e}-05^{*}$ & & \\
\hline Civil status & & $-0.0982343 * *$ & & \\
\hline Family size & & & & $-0.172816^{*}$ \\
\hline $\mathrm{R}^{2}$ & 0.45 & & 0.40 & \\
\hline Number of observations & 1,477 & & 3,518 & \\
\hline$*$ Significant to $1 \%$; ** to $5 \%$ & & & & \\
\hline
\end{tabular}

The results of the Heckman model in all variables are statistically significant and with the expected sign. In this sense, a difference is observed in the sheepskin effect in favor of people who reside in 
urban areas and are men. The value of the coefficient of the experience variable indicates that each year of experience contributes $3.7 \%$ of additional income to people. The negative sign of experience squared shows a concave income function concerning the experience. In this regard, by dividing the experience coefficient by the experience coefficient squared by 2 , the absolute value of the year of experience in which the income function reaches its maximum can be calculated, this is equal to 36 , both in the year 2002 as 2018. In this calculation, there is a similarity with the research carried out by Merlo (2009) for Chile, which estimated in 34 years of experience the moment in which a person reaches the maximum in their salary income in that country. In practice, it is observed that workers in Guatemala reach the maximum salary after having 41 years of experience (IGSS, 2016), a figure slightly higher than that estimated in this research. The calculations show the existence of the sheepskin effect in the three educational levels analyzed. Thus, for example, in 2002 a person with a high school degree obtained 54\% more income, compared to $23 \%$ of a person without said academic credential. In the case of university and postgraduate studies, the award for the degree is more than $100 \%$. In the inter-temporal analysis, a reduction in returns is observed in all variables, except those of secondary and incomplete post-university, concerning 2002. The greatest reductions in the sheepskin effect are observed in the secondary education levels and complete university. The reduction in returns to education had already been documented by a previous study by the author (Díaz 2019), in which it was indicated that this phenomenon coincides with the global trend evidenced in a World Bank study (2014) that describes a reduction in returns to education since the 1980s, as a result of an increase in the years of schooling in the world. Despite the above, in Guatemala, it is still profitable to obtain an academic degree, especially a university degree. It is more so than in the Dominican Republic (Parodi, Ramírez and Thompson, 2017), Colombia (Hernández, 2017), and Chile (Merlo, 2009), countries in which the sheepskin effect for university studies does not exceed 50\%, while in Guatemala it is greater than 100\%. The estimation of the sheepskin effect according to the sex variable only had statistical significance with the ordinary least squares model. In the Heckman model, the existence of selection bias in the separation between both sexes could not be verified. The results for men are presented in Table 4 and show the existence of the sheepskin effect in the three educational levels analyzed.

Table4. Guatemala: Sheepskin effect. Mens.

\begin{tabular}{|l|l|l|}
\hline Variable & 2002 & 2018 \\
\hline Area & $0.08159^{*}$ & $0.152360^{*}$ \\
\hline Experience & $0.035748^{*}$ & $0.033528^{*}$ \\
\hline Experience squared & $-0.000341^{*}$ & $-0.000304^{*}$ \\
\hline High school incomplete & $0.189189^{*}$ & $0.187474^{*}$ \\
\hline High school complete & $0.416612^{*}$ & $0.390989^{*}$ \\
\hline College incomplete & $0.641842^{*}$ & $0.665101^{*}$ \\
\hline College complete & $1.18861^{*}$ & $0.953471^{*}$ \\
\hline Postgraduate incomplete & $1.0025^{*}$ & $1.14122^{*}$ \\
\hline Postgraduate complete & $1.67189^{*}$ & $1.25509^{*}$ \\
\hline Constant & $6.45410^{*}$ & $6.74454^{*}$ \\
\hline $\mathrm{R}^{2}$ & 0.46 & 0.42 \\
\hline Number of observations & 969 & 2351 \\
\hline$*$ Significant to 1\%;** to 5\% & \\
\hline Source: Own calculations based on NSI, 2002 and 2018. & \\
\hline
\end{tabular}

The comparative analysis shows no greater variation in the sheepskin effect at the secondary educational level. In the following two educational levels, there is a reduction in the amount of the sheepskin effect and an increase in the incomplete level, especially in the post-university level, which increased from $100 \%$ in 2002 to $114 \%$ in 2018 . Likewise, the performance among those who earned their title at this level dropped from $167 \%$ to $125 \%$, respectively. The results for the female sex are presented in Table 5, in which a small reduction is observed in the area variable, which as the positive result corresponds to the urban one and an increase of almost half a percentage point in the experience variable.

Table5. Guatemala: Sheepskin effect. Women.

\begin{tabular}{|l|l|l|}
\hline Variable & 2002 & 2018 \\
\hline Area & $0.14588^{* *}$ & $0.139506^{*}$ \\
\hline Experience & $0.031325^{*}$ & $0.037993^{*}$ \\
\hline
\end{tabular}


Sheepskin Effect in Guatemala. Years 2002 and 2018.

\begin{tabular}{|l|l|l|}
\hline Experience squared & $-0.000266^{*}$ & $-0.000364^{* *}$ \\
\hline High school incomplete & $0.229163^{*}$ & $0.242294^{*}$ \\
\hline High school complete & $0.377755^{*}$ & $0.465152^{*}$ \\
\hline College incomplete & $0.598934^{*}$ & $0.594597^{*}$ \\
\hline College complete & $1.01891^{*}$ & $0.945646^{*}$ \\
\hline Postgraduate incomplete & $1.17861^{*}$ & $1.22797^{*}$ \\
\hline Postgraduate complete & $1.93374^{*}$ & $1.38462^{*}$ \\
\hline constant & $6.32862^{*}$ & $6.547950^{*}$ \\
\hline $\mathrm{R}^{2}$ & 0.43 & 0.37 \\
\hline Number of observations & 508 & 1167 \\
\hline$*$ Significant to 1\%;** to 5\% & \\
\hline Source: Own calculations based on NSI, 2002 and 2018. \\
\hline
\end{tabular}

The sheepskin effect presents different results according to educational level. In secondary school, it increased in the two years studied, both for incomplete and complete studies. At the full university and post-university levels, there was a devaluation of the degree. In the first case, the sheepskin effect decreased from $101 \%$ to $95 \%$ and in the second from 193\% to 138\%, for the years 2002 and 2018 . When comparing between sexes, it is observed that the sheepskin effect in the two years investigated is greater in women for the post-university level, both incomplete and complete.

\section{CONCLUSION}

The statistical data analyzed for the years 2002 and 2018 show differences in favor of men compared to women in terms of years of study, work experience, and salary.

The calculations show the existence of the sheepskin effect in high school, college, and postgraduate. The highest amount of the sheepskin effect, in the years studied, is observed at the level of complete college compared to incomplete college.

The results show a devaluation of academic degrees, especially at the university level. Despite this, in Guatemala obtaining a university degree provides a high return.

\section{REFERENCES}

[1] Alejos, L. (2006). "Job choice and returns to education in Guatemala." Journal of Social Studies, (73), 1112.

[2] Becker, G. (1962). "Investment in human capital: A theoretical analysis". The Journal of Political Economy. 70 (5), 9-49.

[3] Díaz, G. (2019). "Decrease in returns to education in Guatemala." Atlantic Review of Economics 2 (1), 127.

[4] DIGI. (2014). The follow-up to graduates of the University of San Carlos. Guatemala: USAC. Harmon, C., Oosterbeek, H., \& Walker, I. (2003). "The Returns to Education: Microeconomics". Journal of Economic Surveys, 17 (2), 115-156. https://doi.org/10.1111/1467-6419.00191.

[5] Hernández, L. (2017). Identification of potential sheepskin effects through spline regressions: Evidence for men and women year 2017. Retrieved on November 30, 2020, from https://expeditiorepositorio. utadeo.edu.co/handle/20.500.12010/7697

[6] Hungerford, T., \& Solon, G. (1987). "Sheepskin Effects in the Return to Education". The Review of Economics and Statistics, 69 (1), 175-177

[7] Guatemalan Institute of Social Security. (2016). Membership bulletin 2016. Guatemala: Author.

[8] Statistics National Institute. (2003). National Survey of Employment and Income. 2002. Retrieved on November 30, 2020, from https://www.ine.gob.gt/ine/estadisticas/bases-de-datos/encuesta-nacional-deempleo-e-ingresos/

[9] Statistics National Institute. (2016). The Republic of Guatemala. Education Compendium 2015. Retrieved on November 30, 2020, from https://www.ine.gob.gt/ine/estadisticas/bases-de-datos/educacion/

[10] Statistics National Institute. (2018). National Survey of Employment and Income. 2016. Retrieved on November 30, 2020, from https://www.ine.gob.gt/index.php/encuestas/empleo-e-ingresos

[11] Statistics National Institute. (2019). XII National Census of Population and VII of Housing 2018. Retrieved on December 2, https://www.censopoblacion.gt/descarga

[12] Klapp, F. and Candia, A. (2016). Estimation of the award or return to education in Chile. Santiago de Chile: Freedom and Development. 
[13] Layard, R. and Psacharopoulos, G. (74), "The screening hypothesis and the returns to education", Journal of Political Economy, (82), 985-998.

[14] Merlo, J. (2009). Returns to education during an economic depression. Empirical evidence for Argentina. Retrieved on December 2, 2020, from http://economia.uc.cl/docs/tesis_jjmerlo.pdf

[15] Mincer, J. (1974). Schooling, experience, and earnings. National Bureau of Economic Research. Retrieved on December 2, 2020, from http://papers.nber.org/books/minc74-1.

[16] Ministry of Education. (2019). National Graduate Report 2018. Guatemala: Author.

[17] Ordaz, J. (2007). "Mexico: human capital and income. Return to education, 1994-2005 ". Studies and perspectives, (90), 1-70.

[18] Parodi, S., Ramírez, I. and Thompson, J. (2017). Rate of return on investment in education in the Dominican Republic (2000-2015). IDB Technical Note; 1325.

[19] Pérez, A. (2003). Education and income: return to education in Guatemala. Guatemala: Rafael Landívar University.

[20] Rivera, J. (2015). Return to education in Ecuador: Between wage gaps and specialized markets. Retrieved on December 2, 2020, from http://repositorio.uasb.edu.ec/handle/10644/4295

[21] Saidón, M. (2004). Returns to education in Guatemala: cost discounts through a simulation. Guatemala: Rafael Landívar University.

[22] Spence, M. (2002). "The signage and the information structure of the markets." Asturian Journal of Economics. (25), 49-94.

[23] Stiglitz, J. (2002). "Information and the change in the paradigm of economic science." Asturian Journal of Economics. (25), 95-164.

[24] World Bank. (2011). Better jobs in Guatemala. The role of human capital. Washington: Author.

Citation: Guillermo Díaz. "Sheepskin Effect in Guatemala. Years 2002 and 2018." International Journal of Humanities Social Sciences and Education (IJHSSE), vol 8, no. 6, 2021, pp. 49-55. doi: https://doi.org/10.20431/2349-0381.0806007.

Copyright: () 2021 Authors. This is an open-access article distributed under the terms of the Creative Commons Attribution License, which permits unrestricted use, distribution, and reproduction in any medium, provided the original author and source are credited. 